\title{
Penerapan Produksi Bersih Dalam Upaya Penurunan Timbulan Limbah Cair Di Pabrik Gula Tebu
}

\author{
Yudith Vega Paramitadevi ${ }^{1}$, Risa Nofriana ${ }^{2)}$, antin Yulisa ${ }^{3)}$ \\ 1), 2), 3) Program Diploma IPB-Teknik dan Manajemen Lingkungan \\ Jalan Kumbang No. 14, Bogor \\ E-mail:vega_paramitadevy@yahoo.com
}

\begin{abstract}
Abstrak
Tebu (Saccharum officianarum L.) adalah tanaman yang mempunyai banyak manfaat, salah satunya sukrosa yang terdapat pada batang tebu yang dimanfaatkan untuk menghasilkan kristal gula. Kristal gula yang terbentuk mengalami pemrosesan yang panjang, dimulai dari penggilingan tebu hingga pemasakan. Pada proses pengolahan tersebut akan menghasilkan gula produk sekaligus limbah cair yang memiliki beban pencemaran organik tinggi. Tindak produksi bersih dalam industri gula tebu diperlukan agar penghematan air baku dan pencemaran air dapat terlaksana. Kajian terhadap produksi bersih dilakukan melalui studi kasus yang sifatnya deskriptif pada salah satu industri gula tebu di Indonesia. Identifikasi terhadap peluang produksi bersih dilakukan agar diperoleh pengaruh keseluruhan terhadap kinerja lingkungan, terutama pengurangan terhadap beban influen yang masuk ke IPAL. Sebanyak 6 alternatif peluang produksi bersih untuk penghematan konsumsi air baku dan 4 alternatif peluang produksi bersih untuk reduksi timbulan limbah cair diberikan. Peluang produksi bersih yang akhirnya dapat diterapkan yakni recycle air kondensat larutan gula, air bekas scrubber dan penerapan good house keeping. Debit air yang masuk ke IPAL berkurang 51.72\%, setara dengan $4500 \mathrm{~m}^{3}$ air baku per hari, atau penghematan sebesar $\mathrm{Rp}$ 17.235.310,00 per tahun. Perancangan desain IPAL ulang juga diusulkan untuk mengatasi permasalahan konvensional yang melekat pada sistem kolam anaerobik-aerobik.
\end{abstract}

Kata Kunci: industri gula, produksi bersih, beban IPAL, recycle air and good house keeping

\begin{abstract}
Sugar cane (Saccharum officianarum L.) is a plant that has many benefits, one of which is sucrose contained in sugar cane used to produce sugar crystals. Sugar crystals are formed undergo lengthy processing, starting from the cane cutting until sugar crystals drying. The treatment process will be produced sugar products along with wastewater that has high organic pollution loading. Cleaner production in the sugar cane industry is required so that the raw water saving and wastewater pollution prevention can be accomplised. The study on cleaner production is done through case study in one of the sugar cane industry in Indonesia by means descriptive analysis. Identification of cleaner production opportunities is done in order to obtain the overall effect on the environmental performance, especiallu the reduction of the organic loading that become wastewater treatment plant influent. A total of 6 alternative cleaner production opportunities for saving the consumption of raw water and 4 alternative cleaner production for the reduction of wastewater generation is given. Cleaner production opportunities that can eventually be applied i.e recycling condensate water of sugar solution, scrubber make up water and implementation of good house keeping. Wastewater discharge is reduced by $51.72 \%$, equivalent to $4500 \mathrm{~m} 3$ of raw water per day, or a savings of IDR 17.235.310,00 per year. Redesigning the wastewater treatment plant is also proposed to solve the conventional problems inherent in anaerobic-aerobic lagoon system.
\end{abstract}

Key Words : sugar cane industry, cleaner production, WWTP loading, water recycling and good house keeping

\section{PENDAHULUAN}

Industri pangan adalah salah satu industri terbesar di dunia. Meskipun industri pangan tidak dinilai sebagai industri yang menghasilkan dampak berbahaya bagi lingkungan, tetap saja dapat menimbulkan pencemaran bagi ekosistem jika tidak memperhatikan keberlanjutan terhadap lingkungan. Industri pangan, terutama gula memiliki berbagai permasalahan yang timbul, antara lain (Ramjeawon 2000; Wei dan Xu 2004; Solomon 2005; Gunkel, et al. 2007; Ingaramo, et al. 2009; Yani, et al. 
2012; Bhatnagar, et al. 2016; Morar, et al. 2016):

1. Konsumsi air bersih yang besar, hal ini dapat menimbulkan masalah bagi negara-negara yang mengalami kesulitan air bersih.

2. Timbulan limbah cair dengan konsentrasi organik polutan yang tinggi.

3. Timbulan lumpur dan limbah padat yang besar.

Dalam

rangka

mengatasi

permasalahan tersebut, industri gula sebaiknya mengadaptasi metode produksi bersih dibandingkan metode konvensional end of pipe treatment (Ramjeawon 2000; Ingaramo, et al. 2009). Metode produksi bersih dapat mengurangi pemakaian air melalui teknik resirkulasi, limbah cair dengan konsentrasi organik polutan yang tinggi dapat diolah dengan teknologi high load wastewater, lumpur dan limbah padat dapat digunakan kembali (Wei dan Xu 2004; Solomon 2005).

Indonesia pada tahun 2013 memiliki 62 unit pabrik gula tebu dengan rincian 50 unit dikelola BUMN dan 12 unit dikelola swasta (Kumalaningsih 2014). Setiap tahunnya, total produksi gula tebu di Indonesia mencapai 2.5 juta ton atau memenuhi sekitar $1.3 \%$ kebutuhan gula di dunia. Produksi 2.5 juta ton gula tersebut disumbangkan dari luas area $454000 \mathrm{Ha}$ dengan produktivitas 11,11 ton tebu per $\mathrm{Ha}$ serta penyerapan karyawan sebesar 900 000 orang (Direktorat Jenderal Perkebunan 2009). Jumlah produksi gula tersebut hanya mampu memenuhi kebutuhan konsumen non industri dalam negeri, kebutuhan gula di Indonesia masih disuplai sebesar 2.3 juta ton dari luar negeri, khususnya Thailand (Direktorat Jenderal Industri Agro dan Kimia 2009). Kontribusi utama penghasil tebu adalah Jawa Timur (43.29\%), Jawa Tengah (10.07\%), Jawa Barat (5.87\%) dan Lampung (25.71\%) (Direktorat Jenderal Perkebunan 2009).

$$
\text { Industri gula di Indonesia }
$$
menggunakan air bersih sebagai bahan baku utama, disamping menghasilkan limbah cair yang berpotensi besar mencemari badan air. Kesadaran terhadap dampak lingkungan di kalangan pengusaha gula dan peraturan pemerintah mengenai baku mutu limbah cair di industri gula, menimbulkan usaha-usaha perbaikan dalam pengelolaan air bersih dan limbah cair. Industri gula, khususnya gula tebu menghadapi tantangan dalam hal efisiensi sumber daya alam, yakni menghasilkan produk optimum dari bahan baku yang minimum. Studi kasus diambil dari salah satu perusahaan tebu milik swasta asing di Kabupaten Lampung Tengah, Provinsi Lampung yakni PT XYZ. Tujuan dari penelitian ini adalah mengidentifikasi potensi produksi bersih pada industri studi kasus untuk meminimalisasi beban limbah cair yang keluar dari pabrik sebelum masuk unit pengolahan limbah cair.

\section{METODOLOGI PENELITIAN}

Penelitian tentang penerapan produksi bersih di PT XYZ ini dilakukan dengan pendekatan penelitian kulitatif dan kuantitatif. Metode penelitian yang digunakan adalah studi kasus yang bersifat deskriptif. Peneliti berupaya untuk mengkaji upaya penerapan konsep produksi bersih yang dilaksanakan, untuk selanjutnya dibuat suatu evaluasi pengaruhnya terhadap kinerja lingkungan.

Penelitian diawali dari adanya proses produksi gula tebu yang berpotensi mencemari lingkungan dengan menghasilkan limbah cair, emisi udara dan limbah padat. Identifikasi awal dilakukan pada tahapan proses produksi, penggunaan air serta timbulan limbah pada tiap tahapan proses produksi. Langkah selanjutnya adalah dengan mengidentifikasi konsumsi air baku dan sumber penyebab timbulan limbah sebagai dasar peluang penerapan produksi bersih. Alternatif produksi bersih kemudian dianalisis kelayakannya secara lingkungan dengan potensi pengurangan konsumsi air baku dan timbulan limbah.

\section{HASIL DAN PEMBAHASAN \\ Konsumsi Air Baku untuk Proses Produksi}

Air baku diperlukan untuk proses sebagai berikut:

1. Ekstraksi, sebagai air imbibisi untuk memperbaiki ekstraksi gula dari ampas, dan sebagai air pendingin bagi mesin yang mengekstraksi gula.

2. Evaporasi, sebagai air umpan untuk barometrik kondensor.

3. Kristalisasi, sebagai air pendingin untuk tangki-tangki massecuite.

4. Pembangkitan energi (power generation), sebagai air pendingin turbo-alternator untuk menghasilkan listrik (pembakaran bagasse), sebagai air umpan boiler, sebagai air umpan untuk furnace flue-gas scrubber.

5. Pembantu seperti air pendingin pompa, pembersihan industri dan persiapan pembuatan susu kapur. 
PT XYZ secara garis besar memproduksi gula tebu sebesar 12000 ton tebu per hari (12 000 TCD), menggunakan air baku sebesar $0.33 \mathrm{~m}^{3} /$ ton tebu $\left(\mathrm{m}^{3} / \mathrm{tc}\right)$ selama on session dan menghasilkan limbah cair dengan debit $0.31 \mathrm{~m}^{3} / \mathrm{tc}$ selama on session. Selama off session, PT XYZ menggunakan air baku sebesar $0.35 \mathrm{~m}^{3} / \mathrm{tc}$ dan menghasilkan limbah cair dengan debit $0.33 \mathrm{~m}^{3} / \mathrm{tc}$. Gambar 1 menunjukkan konsumsi air secara detail di PT XYZ.
Berdasarkan Gambar 1 tersebut, proses produksi yang membutuhkan banyak air baku adalah kondenser barometrik selama proses kondensasi, dan scrubber gas buang selama proses pembakaran bagasse. Sebenarnya konsumsi air dapat dikurangi apabila perusahaan menerapkan penggunaan air kembali (recycle). Recycle air adalah peluang bagi perusahaan dalam menerapkan produksi bersih.

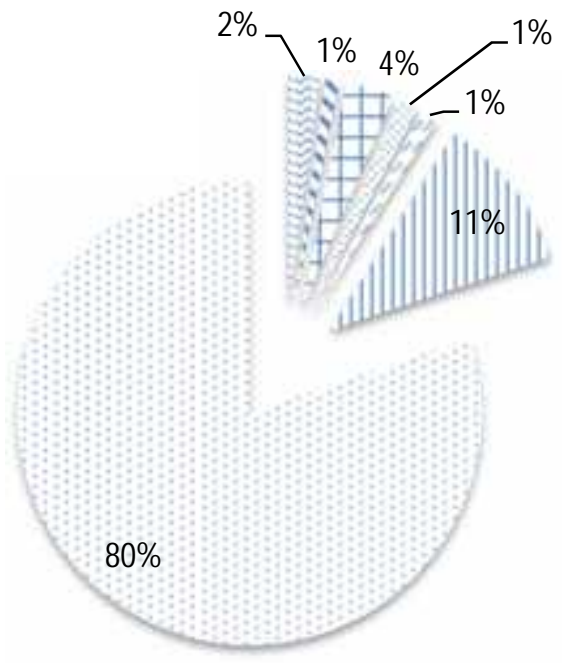

\author{
$\approx$ Air imbibisi \\ Air pendingin : turbo-alternator \\ F Air pendingin : milling tandem \\ Air pendingin : kristalizer \\ Air make-up boiler \\ II Umpan scrubber
}

Air make-up kondenser

Gambar 1 Konsumsi air baku secara detail di PT XYZ

\section{Sumber Limbah Cair}

Limbah pabrik gula yang paling mendapatkan perhatian adalah limbah cair, karena limbah cair inilah yang paling banyak menimbulkan dampak lingkungan. Pada umumnya proses giling pabrik gula di Indonesia berlangsung pada saat musim kemarau saat debit air sungai rendah (Yani, et al. 2012). Pembuangan air limbah ke sungai akan memberikan beban pencemaran yang cukup tinggi terhadap sungai maupun lahan pertanian, sehingga sebelum pelepasan limbah, harus didahului oleh pertimbangan dan penelitian dengan seksama.
Konsentrasi polutan yang terdapat dalam limbah cair hasil proses produksi PT XYZ dapat dilihat dalam Tabel 1. Semakin banyak tonase gula tebu yang dihasilkan, beban pencemaran akan semakin tinggi. Berdasarkan Tabel 1 juga, sumber utama limbah cair adalah sisa air pendingin dan pencucian alat. Limbah cair tersebut mengandung konsentrasi bahan organik yang berasal dari gula terlarut. Limbah cair bersuhu tinggi berasal dari air bekas kondensat dan blowdown boiler, sedangkan air bekas yang mengandung fly ash dari scrubber terdapat konsentrasi padatan tersuspensi yang tinggi.

Tabel 1 Sumber dan karakteristik pencemar di PT XYZ

\begin{tabular}{|c|c|c|c|c|c|c|c|c|c|c|c|c|}
\hline \multirow{2}{*}{$\begin{array}{l}\text { Sumber } \\
\text { Limbah } \\
\text { Cair }\end{array}$} & \multicolumn{2}{|c|}{ Debit } & \multicolumn{2}{|c|}{$\mathrm{BOD}_{5}$} & \multicolumn{2}{|c|}{ COD } & \multicolumn{2}{|c|}{ TSS } & \multicolumn{2}{|c|}{ Minyak } & \multirow[t]{2}{*}{$\mathrm{pH}$} & \multirow{2}{*}{$\begin{array}{l}\text { Suhu } \\
\left({ }^{0} \mathrm{C}\right)\end{array}$} \\
\hline & $\mathrm{m}^{3} / \mathrm{tc}$ & $\mathrm{m}^{3} /$ hari & $\mathrm{mg} / \mathrm{L}$ & $\mathrm{kg} /$ hari & $\mathrm{mg} / \mathrm{L}$ & $\mathrm{kg} / \mathrm{hari}$ & $\mathrm{mg} / \mathrm{L}$ & $\mathrm{kg} / \mathrm{hari}$ & $\mathrm{mg} / \mathrm{L}$ & $\mathrm{kg} / \mathrm{hari}$ & & \\
\hline $\begin{array}{l}\text { sisa } \\
\text { cooling }\end{array}$ & & & & & & & & & & & & \\
\hline $\begin{array}{l}\text { water dan } \\
\text { pencucian } \\
\text { alat }\end{array}$ & 0,041 & 492 & 610 & 5,48 & 1433 & 12,87 & 163 & 1,46 & 23 & 0,2 & 6,2 & 27 \\
\hline $\begin{array}{l}\text { air bekas } \\
\text { kondensat }\end{array}$ & 0,041 & 492 & 127 & 1,14 & 266 & 2,38 & 2 & 0,02 & - & & 7,6 & 72 \\
\hline air & 0,027 & 328 & 44 & 0,39 & 126 & 1,14 & 31 & 0,28 & - & & 10,1 & 81 \\
\hline
\end{tabular}




\begin{tabular}{|c|c|c|c|c|c|c|c|c|c|c|c|c|}
\hline \multirow{2}{*}{$\begin{array}{l}\text { Sumber } \\
\text { Limbah } \\
\text { Cair }\end{array}$} & \multicolumn{2}{|c|}{ Debit } & \multicolumn{2}{|c|}{$\mathrm{BOD}_{5}$} & \multicolumn{2}{|c|}{ COD } & \multicolumn{2}{|c|}{ TSS } & \multicolumn{2}{|c|}{ Minyak } & \multirow[t]{2}{*}{$\mathrm{pH}$} & \multirow{2}{*}{$\begin{array}{l}\text { Suhu } \\
\left({ }^{0} \mathrm{C}\right)\end{array}$} \\
\hline & $\mathrm{m}^{3} / \mathrm{tc}$ & $\mathrm{m}^{3} /$ hari & $\mathrm{mg} / \mathrm{L}$ & kg/hari & $\mathrm{mg} / \mathrm{L}$ & kg/hari & $\mathrm{mg} / \mathrm{L}$ & $\mathrm{kg} / \mathrm{hari}$ & $\mathrm{mg} / \mathrm{L}$ & kg/hari & & \\
\hline $\begin{array}{l}\text { blowdown } \\
\text { boiler } \\
\text { air bekas } \\
\text { scrubber } \\
\text { air bekas }\end{array}$ & 0,014 & 164 & 34 & 0,3 & 510 & 4,58 & 702 & 6,3 & - & & 8,5 & 42 \\
\hline $\begin{array}{l}\text { spray- } \\
\text { pond }\end{array}$ & 0,221 & 2668 & 20 & 0,18 & 46 & 0,42 & 26 & 0,23 & - & & 7,1 & 40 \\
\hline Total & 0,343 & 4144 & & 7,49 & & 21,38 & & 8,3 & & 0,2 & & \\
\hline
\end{tabular}

Limbah cair dari sisa air pendingin dan pencucian alat mengandung $73 \%$ polutan organik, meskipun hanya menyumbang $12 \%$ debit limbah cair. Sumber limbah cair tersebut dihasilkan diluar proses produksi, yakni saat hari libur (biasanya hari Minggu) dan saat off season. Konsentrasi $\mathrm{BOD}_{5}$ dapat mencapai lebih dari $4000 \mathrm{mg} / \mathrm{L}$ saat pencucian alat di hari libur dan lebih dari 20 $000 \mathrm{mg} / \mathrm{L}$ saat pembersihan tangki kristalisasi di masa off season.

Gambar 3 menunjukkan perbandingan antara efluen Instalasi Pengolah Air Limbah (IPAL) PT XYZ dan peraturan Gubernur
Lampung no 7 tahun 2010 tentang Baku Mutu Air Limbah (BMAL) Industri Gula dan Gula Rafinasi. Rerata konsentrasi efluen limbah cair pada bulan April 2014-Maret 2015 masih di bawah baku mutu, meskipun sebenarnya untuk konsentrasi COD mencapai $102 \mathrm{mg} / \mathrm{L}$ saat on season. Pada hari libur dan saat off season terkadang timbul bau yang tidak enak di sekitar sungai Putek, tempat PT XYZ membuang limbah cairnya. Hal-hal tersebut merupakan permasalahan yang harus ditangani oleh PT

XYZ.

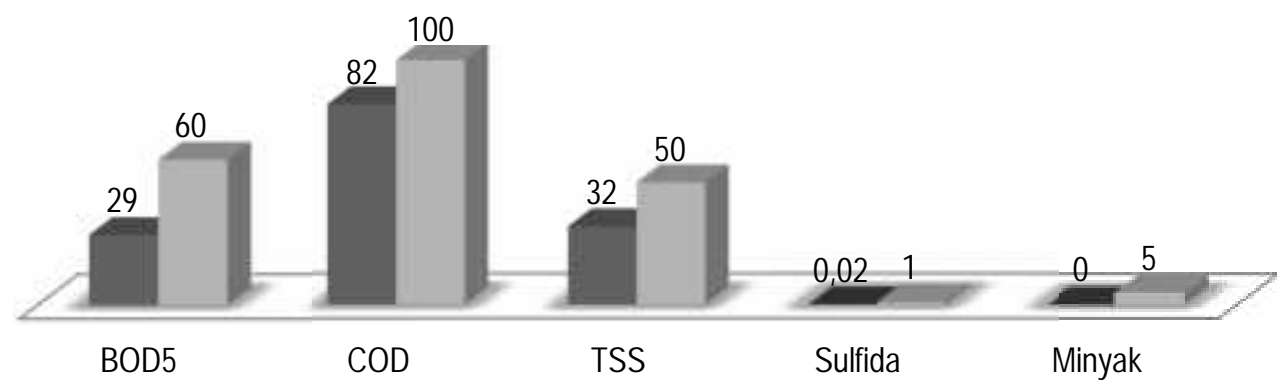

Gambar 3 Rerata efluen limbah cair PT XYZ tahun 2014-2015 dibandingkan dengan BMAL

\section{Peluang Produksi Bersih untuk Penghematan Konsumsi Air Baku}

Upaya untuk mengatasi limbah cair selain teknologi end-of-pipe treatment adalah mengurangi penggunaan air baku. Keuntungan dari konservasi air adalah penghematan sumber daya air. Menurut Bantacut dan Novitasari (2016), kebutuhan air baku untuk satu kali siklus produksi di pabrik gula tebu sekitar 12 ton air per ton tebu. Apabila suatu pabrik menggunakan proses penggunaan air kembali baik sebagian atau seutuhnya, akan dapat mengurangi penggunaan air 1.5 hingga 2 ton per ton gula tebu. Beberapa peluang konservasi air sebagai alternatif untuk PT $\mathrm{XYZ}$ ada dalam uraian berikut.
1. Pilihan 1 : Kolam spray untuk penggunaan kembali air pendingin dari kondenser barometrik.

Seperti yang ada dalam Gambar 3, air pendingin dari kondenser barometrik merupakan jumlah konsumsi air terbesar di PT XYZ. Air buangan dalam proses ini dapat digunakan kembali dengan mengaplikasikan cooling tower atau kolam spray yang dapat mengurangi perbedaan suhu awal dan akhir di kondenser. Dengan memperhitungkan evaporasi dan kecepatan angin, kolam spray kurang lebih dapat menghemat air hingga $0.195 \mathrm{~m}^{3} / \mathrm{tc}$. Biaya investasi sekitar 6.5 triliun rupiah dan biaya operasional tahunan sebesar 651 juta rupiah. 
2. Pilihan 2 : Pemeliharaan dan penggunaan kembali air bekas proses scrubber.

Air bekas dari proses scrubbing dapat disaring dan digunakan kembali sebagai air umpan. Timbulan fly ash dapat dikeringkan dan dimanfaatkan oleh pihak ke tiga. Dengan memperhitungkan evaporasi dan kandungan air fly ash, estimasi air baku dapat dihemat sebesar 0.06 $\mathrm{m}^{3} / \mathrm{tc}$. Biaya investasi sekitar 2.6 miliar rupiah dan biaya operasional tahunan sebesar 195 juta rupiah.

3. Pilihan 3 : Penggunaan kembali air sisa kondensat.

Kondensat dari proses evaporasi selain dapat dijadikan sebagai air umpan boiler, dapat juga digunakan kembali sebagai air imbibisi, air umpan scrubber, air make up di barometrik kondenser dan untuk pencucian alat. Kurang lebih $0.1 \mathrm{~m}^{3} / \mathrm{tc}$ air baku dapat dihemat. Biaya investasi sebesar 976 juta rupiah (untuk penyimpanan air panas, pemompaan dan sebagainya) dan biaya operasional tahunan sebesar 65 juta rupiah.

4. Pilihan 4 : Penggunaan kembali air pendingin dari turbo machinery.

Instalasi cooling tower (kapasitas 100 $\mathrm{m} /$ jam) dapat merecycle air dari mesin-mesin pabrik. Bearing mesin menghasilkan minyak dan lemak, harus ditambahkan pemisah dalam proses tersebut. Kurang lebih 0.01 $\mathrm{m}^{3} / \mathrm{tc}$ air baku dapat dihemat. Biaya investasi sebesar 1.3 miliar rupiah dan biaya operasional tahunan sebesar 260 juta rupiah.

5. Pilihan 5 : Penggunaan kembali limbah cair.

Air baku yang digunakan untuk pembersihan pabrik selama hari libur dan masa off season mengandung konsentrasi organik yang tinggi.
Limbah cair dapat digunakan kembali sebagai air umpan untuk barometrik kondenser dan scrubber, pembersihan pabrik atau irigasi. Estimasi air baku dapat dihemat hingga $0.15 \mathrm{~m}^{3} / \mathrm{tc}$, dengan biaya investasi sebesar 2 miliar rupiah dan biaya operasional tahunan sebesar 586 juta rupiah.

Berdasarkan pilihan 1 sampai dengan 6, jumlah air baku terbesar yang dapat dihemat berasal dari pilihan 1 yakni instalasi kolam spray. Meskipun demikian, perusahaan menerapkan pilihan 2 dan 3 untuk meningkatkan kinerja lingkungan, mengurangi fly ash dan mengurangi penggunaan air baku dari sumur bor. Setelah pilihan 2 dan 3 diterapkan, PT XYZ dapat menghemat penggunaan air baku hingga $1920 \mathrm{~m}^{3}$ per hari.

\section{Kondisi IPAL Eksisting di PT XYZ}

Sumber limbah cair di PT XYZ yang berpotensi mencemari lingkungan dan membutuhkan pengolahan yaitu :

1. Lumpur yang mengandung fly ash dari gas buang alat scrubber dalam pembakaran bagasse.

2. Limbah cair hasil pencucian alat saat hari libur dan off season, serta limbah cair bekas air pendingin.

Sistem IPAL di PT XYZ menggunakan sistem konvensional biologis dengan kapasitas $245092 \mathrm{~m}^{3}$ dan waktu tinggal 55 hari. Tabel 2 menunjukkan luas dan kapasitas kolam IPAL di PT XYZ. IPAL dilengkapi dengan 11 unit surface aerator yang masing-masing berkekuatan $15 \mathrm{~kW}$ sebagai pemasok kebutuhan oksigen dalam proses pengolahan air limbah, dan juga terdapat dua unit pompa transfer vertikal untuk mengalirkan air limbah.

Tabel 2 Luas dan kapasitas kolam IPAL di PT XYZ

\begin{tabular}{lccc}
\hline \multicolumn{1}{c}{ Nama Kolam } & $\begin{array}{c}\text { Luas } \\
\left(\mathrm{m}^{2}\right)\end{array}$ & Volume $\left(\mathrm{m}^{3}\right)$ & $\begin{array}{c}\text { HRT } \\
\text { (Hydraulic Retention } \\
\text { Time })\end{array}$ \\
\hline $\begin{array}{l}\text { Pemisah Minyak dan Penangkap } \\
\text { Padatan 1 }\end{array}$ & 200 & 800 & 5 jam \\
$\begin{array}{l}\text { Pemisah Minyak dan Penangkap } \\
\text { Padatan 2 }\end{array}$ & 200 & 800 & 5 jam \\
Ekualisasi & 5940 & 29700 & 7 hari \\
Anaerob & 10100 & 60900 & 15 hari \\
Fakultatif I & 2800 & 8400 & 2 hari \\
Fakultatif II & 2800 & 8400 & 2 hari \\
Fakultatif III & 9637 & 31500 & 8 hari \\
\hline
\end{tabular}




\begin{tabular}{|c|c|c|c|}
\hline Nama Kolam & $\begin{array}{l}\text { Luas } \\
\left(\mathrm{m}^{2}\right)\end{array}$ & Volume $\left(\mathrm{m}^{3}\right)$ & $\begin{array}{c}\text { HRT } \\
\text { (Hydraulic Retention } \\
\text { Time) }\end{array}$ \\
\hline Fakultatif IV & 7973 & 32700 & 8 hari \\
\hline Fakultatif V & 2040 & 6120 & 2 hari \\
\hline Aerasi I & 10364 & 18654 & 5 hari \\
\hline Aerasi II & 19127 & 34428 & 8 hari \\
\hline Stabilisasi & 4500 & 8100 & 2 hari \\
\hline Monitor & 2550 & 4590 & 1 hari \\
\hline
\end{tabular}

Air limbah yang mengalir akan melalui kolam pemisah minyak yang berfungsi untuk mengurangi kadar minyak dalam air limbah yang akan diolah. Setelah itu akan dialirkan menuju kolam penyangga atau ekualisasi yang berfungsi sebagai penyetaraan parameter seperti $\mathrm{pH}$ dan suhu dari limbah yang diterima dengan bantuan satu unit aerator.

Limbah yang telah melalui kolam penyangga atau ekualisasi akan dialirkan menuju kolam anaerob dengan kedalaman hingga $6 \mathrm{~m}$. Sebelum masuk ke kolam anaerob, limbah yang keluar dari kolam penyangga telah diinokulasikan bakteri activated growth bacteria (AGB) untuk mempercepat penguraian polutan dalam limbah. Di kolam anaerob terjadi pendegradasian oleh bakteri AGB dengan kedalaman kolam antara 4-6 $\mathrm{m}$.

Hasil kerja bakteri pada kolam anaerob terlihat dari busa yang terdapat di permukaan kolam. Air limbah kemudian kembali dialirkan ke kolam berikutnya, yaitu kolam fakultatif I, aliran menuju kolam ini sebelumnya telah diberikan bakteri super growth bacteria (SGB) yang bersifat aerobik. Jumlah keseluruhan kolam fakultatif adalah lima kolam, kolam fakultatif I-III dibantu oleh dua unit aerator. Pada kolam fakultatif IV limbah didiamkan, dengan tujuan menurunkan TSS. Pada saat menuju kolam fakultatif $\mathrm{V}$ limbah dibuatkan terjunan untuk menambah suplai oksigen dan menurunkan COD.

Air limbah kemudian akan masuk ke kolam aerasi I, pihak PT XYZ menggunakan pipa sebagai transfer ke kolam aerasi I. Pipa ini dibuat untuk melewatkan air di atas sungai Putak, kemudian air limbah akan dipompa ke kolam aerasi I. Kolam aerasi ini dibantu oleh tiga unit aerator dan air mancur pada pipa dengan diameter $10 \mathrm{~cm}$, untuk membantu suplai oksigen pada kolam.

Limbah akan dialirkan menuju kolam aerasi II, selain mendapat bantuan dua unit aerator di kolam ini juga terdapat aplikasi enceng gondok (Eichhornia crassipes) yang diharapkan dapat menurunkan kadar polutan. Limbah ini akan kembali dialirkan ke kolam stabilisasi tanpa perlakuan lain. Kolam terakhir dari rangkaian IPAL ini adalah kolam monitor yang berisi bioindikator ikan nila untuk pemantauan kualitas air limbah.

\section{Peluang Produksi Bersih untuk Pengurangan Timbulan Limbah Cair}

Dalam rangka mengatasi beberapa masalah dalam limbah cair seperti yang telah dikemukakan sebelumnya, beberapa tindak good house keeping (GHK) diperlukan seperti berikut ini :

1. Upaya pengurangan tumpahan, kebocoran dari sistem pendingin dan resirkulasi, serta perawatan mesin untuk mengurangi kebocoran pelumas.

2. Upaya penyisihan minyak dan lemak, dengan sistem parit dan perangkap.

3. Upaya peningkatan kinerja pemisah vacuum evaporator untuk mengurangi gula tebu yang menetes ke dalam barometrik kondenser.

4. Upaya penyimpanan sementara kelebihan larutan gula dari tangki proses dan sistem pemanas selama masa pembersihan, dan pengembalian kelebihan tersebut setelah masa pembersihan usai.

5. Upaya pemrosesan kembali limbah cair yang mengandung konsentrasi ekstrak gula yang tinggi saat off season, dan upaya perbaikan prosedur pencucian alat. Semisal dari seminggu sekali menjadi dua minggu sekali.

Tindakan GHK yang dilaksanakan oleh PT XYZ adalah poin 1, 2, 4 dan perbaikan prosedur pencucian alat. Secara rutin sistem pelumasan peralatan pabrik selalu dipantau oleh petugas khusus dibawah Departemen Teknik. Petugas juga menjaga agar tidak terjadi ceceran minyak pelumas keluar dari sistem pelumasan.

PT XYZ melaksanakan upaya minimisasi limbah cair dengan penataan 
kembali saluran atau parit limbahnya sehingga air yang merupakan polutan dan air yang tidak mengandung polutan dapat dipisahkan alirannya. Pemisahan ini dilakukan dengan membuat parit yang terdiri dari parit $A, B$, dan $C$.

Aliran dari parit $A$ adalah aliran yang berasal dari pembuangan bahan kimia laboratorium sugar technology dan juga dari evaporator pada saat pembersihan kimia dengan menggunakan kaustik soda dan asam sulfamik. Aliran parit A akan menuju kolam balancing yang bertujuan menetralkan bahan kimia dari parit $A$, selama 15 hari didiamkan, setelah itu akan dipompakan menuju IPAL. Kolam balancing ini juga berfungsi untuk menampung air bekas cucian bejana masakan kontinyu yang benyak mengandung kerak gula.

Parit B merupakan saluran yang membawa air yang bersuhu $40-60^{\circ} \mathrm{C}$ tetapi tidak mengandung polutan, yakni air sisa steam kondensat larutan gula. Terdapat pertemuan saluran antara parit A dan B yang kemudian akan dialirkan menuju IPAL.

Parit selanjutnya adalah parit $\mathrm{C}$, yaitu parit yang membawa limbah cair yang mengandung polutan, terutama minyak dan lemak. Polutan ini berasal dari stasiun gilingan di proses produksi dan maintenance day, sebagian besar minyak ini akan dilewatkan pada grease trap sehingga kandungan minyak akan berkurang saat masuk parit C. Ukuran bangunan grease trap adalah panjang $3 \mathrm{~m}$, lebar $2 \mathrm{~m}$ dan tinggi $1 \mathrm{~m}$. Minyak dan lemak yang terkumpul akan ditampung, yang berhasil dipisahkan dikeringkan dari air yang terbawa untuk dibakar di boiler bersama bagasse sebagai bahan bakar.

Pemasangan level kontrol pada tangki penyimpan larutan gula juga dilakukan agar kondisi larutan gula terpantau. Apabila sampai terjadi kehilangan larutan gula, diatasi pula dengan pemasangan pengaman pencegah kebocoran. Upayaupaya GHK tersebut dapat mengurangi debit limbah cair yang masuk ke IPAL hingga $2580 \mathrm{~m}^{3}$ per harinya.

Total air baku yang dapat dihemat dalam pelaksanaan produksi bersih oleh $\mathrm{PT}$ $X Y Z$ sekitar $4500 \mathrm{~m}^{3}$ per hari atau setara dengan penghematan energi listrik sebesar Rp. 17.235.310,00 per tahun. Penelitian sebelumnya yang dilakukan oleh Poddar dan Sahu (2015) di India menunjukkan penghematan sebesar $1980 \mathrm{~m}^{3}$ per hari apabila produksi bersih diterapkan di industri gula tebu. Dengan demikian upaya tindak produksi bersih yang dilakukan dalam penelitian ini sudah cukup efektif.

\section{Rencana Perusahaan untuk Perbaikan IPAL}

Permasalahan yang dihadapi oleh PT $X Y Z$ adalah konsentrasi COD berfluktuasi terhadap BMAL dan bau. Beberapa teknologi yang dapat diterapkan apabila industri gula berniat mendesain IPAL ulang antara lain (Kushwaha 2015; Bhatnagar, et al. 2016):

1. Extended aeration

2. Upflow Anaerobic Sludge Blanket (UASB)

3. Anaerobic Baffled Reactor (ABR)

Tabel 3 merupakan perbandingan dari tiga jenis alternatif untuk mengelola limbah cair di PT XYZ. Berdasarkan Tabel 3 dapat disimpulkan bahwa :

1. Ketiga teknologi tersebut dapat dioperasikan untuk mengatasi masalah bau yang ditimbulkan oleh IPAL eksisting.

2. Masing-masing alternatif teknologi memiliki kelemahan dan kelebihan yang berbeda. Persamaan dari tiga alternatif tersebut adalah kinerja yang tinggi untuk menyisihkan COD.

Tabel 3 Perbandingan tiga jenis alternatif teknologi redesain IPAL di PT XYZ

\begin{tabular}{|c|c|c|c|c|c|}
\hline $\begin{array}{l}\text { Alternatif } \\
\text { Teknologi }\end{array}$ & $\begin{array}{c}\text { Efisiensi } \\
\text { Penyisihan } \\
\text { COD }\end{array}$ & $\begin{array}{l}\text { Kebutuhan } \\
\text { Lahan (Ha) }\end{array}$ & $\begin{array}{l}\text { Kebutuhan } \\
\text { Energi } \\
\text { (kWh) }\end{array}$ & $\begin{array}{c}\text { Investasi Awal } \\
\text { (Rp.) }\end{array}$ & $\begin{array}{c}\text { Biaya Operasional } \\
\text { Tahunan } \\
\text { (\% Investasi Awal) }\end{array}$ \\
\hline Extended & & & & 8.138 .750 .00 & \\
\hline Aeration & $75-85 \%$ & 0,6 & 29 & $\begin{array}{l}0 \\
2.440 .493 .29\end{array}$ & $2 \%$ \\
\hline ABR & $72-99 \%$ & 0,4 & - & $\begin{array}{l}1 \\
2.343 .960 .00\end{array}$ & $<0,05 \%$ \\
\hline UASB & $85-90 \%$ & $<0,1$ & - & 0 & $<0,1 \%$ \\
\hline
\end{tabular}

PT XYZ perlu melakukan penelitian dan pertimbangan pemilihan alternatif teknologi terbaik dalam rangka desain ulang IPAL agar tepat guna dan sesuai dengan kebutuhan, terlebih perusahaan akan memperbesar kapasitas produksi menjadi 16000 TCD sesuai dalam business plannya. 


\section{KESIMPULAN}

Penerapan produksi bersih dapat dilakukan pada industri gula tebu yang berguna untuk meminimalkan dampak terhadap konsumsi sumber daya air dan pencemaran air. Perusahaan tempat studi kasus adalah PT XYZ dengan kapasitas produksi 12.000 TCD, kebutuhan air bersih antara 0,33-0,35 $\mathrm{m}^{3} / \mathrm{tc}$ dan debit limbah cair sebesar $0,31-0.33 \mathrm{~m}^{3} / \mathrm{tc}$. Peluang produksi bersih untuk penghematan konsumsi air baku terdapat 6 pilihan. $\mathrm{PT} \quad \mathrm{XYZ}$ menerapkan pilihan 2 dan 3 yakni penggunaan kembali air bekas scrubber dan air sisa kondensat. Peluang produksi bersih untuk pengurangan timbulan limbah cair adalah penerapan tindak GHK. Sebesar $4500 \mathrm{~m}^{3}$ air baku dapat dihemat per harinya atau Rp. 17.235.310,00 dapat dihemat tiap tahunnya untuk biaya listrik sumur bor. Dalam rangka menghadapi permasalahan IPAL eksisting yakni konsentrasi COD yang fluktuatif terhadap BMAL dan bau, tiga alternatif teknologi diberikan. Hanya saja, alternatif tersebut harus dikaji lebih dalam agar sesuai dengan kebutuhan perusahaan.

\section{DAFTAR PUSTAKA}

Bantacut, Tanjudin, dan Destiara Novitasari. Energy and Water SelfSufficiency Asessment of the White Sugar Production Process in Indonesia using a Complex Mass Balance Model. Journal of Cleaner Production. In press (2016): 1-15.

Bhatnagar, Amit, Kumar Kalindra Kesari, dan Nara Sinha Shurphali. Multidisciplinary Approaches to Handling Wastes in Sugar Industries. Water Air Soil Pollution Journal. 227 (2016): 11-40.

Direktorat Jenderal Industri Agro dan Kimia. Roadmap Industri Gula. Jakarta: Kementerian Perindustrian, 2009.

Direktorat Jenderal Perkebunan. Budidaya Tanaman Tebu. Jakarta: Kementerian Pertanian, 2009.

Gunkel, Gunter, Jan Kosmol, Maria Sobral, Hendryk Rohn, Suzana Montenegro, dan Joana Aureliane. Sugar Cane Industry as a Source of Water Pollution-Case Study on the Situation in Ipojuca River, Pernambuco, Brazil. Water Air Soil Pollution Journal. 180 (2007): 261-269.

Republik Indonesia. Pemerintah Provinsi Lampung. Pergub Lampung No. 7 tahun 2010 tentang Baku Mutu Air Limbah bagi Usaha dan/atau Kegiatan di Provinsi Lampung. Lampung: Pemprov Lampung, 7 Maret 2010.

Ingaramo, Alejandra, Humberto Heluane, Mauricio Colombo, dan Rario Cesca. Water and Wastewater Eco-Efficiency Indicators for The Sugar Cane Industry. Journal of Cleaner Production. 17 (2009): 487-495.

Kumalaningsih, Sri. Pohon Industri Potensial pada Sistem Agroindustri. Malang: University of Brawijaya Press, 2014.

Kushwaha, J.P. A Review on Sugar Industry Wastewater: Sources, Treatment Technology, and Reuse. Desalination and Water Technology Journal. 53 (2015): 309-318.

Morar, Florica, Dana Rus, dan BogdanLonut Jung. The Influence of SugarProcessing Effects on Water in Treatment Plants. Journal of Proceedia Technology. 22 (2016): 486-492.

Poddar, Pradeep Kumar, dan Om Prakash Sahu. Quality and Management of wastewater in sugar industry. Appl Water Sci., 2015: 1-9.

Ramjeawon, T. Cleaner Production in Mauritian Cane-Sugar Factories. Journal of Cleaner Production. 8 (2000): 503-510.

Solomon, Sanjay K. Environmental Pollution and Its Management in Sugar Industry in India : An Appraisal. Sugar Tech Journal. 7, no. 1 (2005): 77-81.

Wei, Yuan-an, dan Yuan-jin Xu. EcoFriendly Management of Sugar Industry Effluents in Guangxi, China. Sugar Tech Journal. 6, no. 4 (2004): 285-290.

Yani, Mohamad, Ikawati Purwaningsih, dan Munandar Mas Nandang. Penilaian Daur Hidup (LCA) Gula pada Pabrik Gula Tebu. E-Jurnal Agroindustri Indonesia. 1, no. 1 (2012): 60-7. 